Journal of Vegetation Science (2008) 19: 457-464.

DOI: 10.3170/2008-8-18382

\title{
Plant traits enabling survival in Mediterranean badlands in northeastern Spain suffering from soil erosion
}

\section{Joaquín Guerrero-Campo ${ }^{2,3}$, Sara Palacio ${ }^{1,4}$ and Gabriel Montserrat-Martí ${ }^{1,}$ *}

${ }^{1}$ Pyrenean Institute of Ecology (CSIC), Av. Montañana, 1005. Apdo. 202. 50192 Zaragoza (Spain).

2 Servicio Provincial de Medio Ambiente, Diputación General de Aragón. Pza. San Pedro Nolasco 7, 50071 Zaragoza, Spain.

${ }^{3}$ E-mail jguerrero@aragon.es ; ${ }^{4}$ s.palacio@macaulay.ac.uk ;

*Corresponding author; E-mail: gmmarti@ipe.csic.es ; Fax +34 976716019

\section{Abstract}

Question: This study analyzed the effect of severe soil erosion on species composition of plant communities by favouring species showing certain growth forms, root-sprouting and clonal growth abilities.

Location: The study area was located between the middle Ebro Valley and the PrePyrenees (northeastern Spain).

Methods: Root-sprouting and shoot-rooting abilities, clonal reproduction and growth form were assessed for the 123 most common plant species from eroded lands in the study area. We obtained 260 vegetation relevés in three different substrata (gypsum outcrops, Miocene clays and Eocene marls) on areas with different degree of soil erosion. The frequency of every plant trait in each relevé was estimated according to species presence. The effect of soil erosion on the frequency of plant attributes was assessed by correlation analyses.

Results: Bipolar, non-clonal plants and annual species decreased their frequency with soil erosion in the three substrata analyzed, whereas root-sprouters and woody plants (mostly sub-shrubs) increased their frequency in most of the substrata analyzed.

Conclusions: Woody sub-shrubs, root-sprouters and clonal species are favoured in eroded lands in NE Spain. Bipolar species and annual plants might not be plastic enough to survive the high stress and frequent disturbances prevailing in such eroded areas.

Key words: Clay, Clonality, Eroded pasture, Functional strategy, Growth form, Gypsum, Marl, Plant life history, Root-sprout, Shoot-borne root.

\section{INTRODUCTION}

Soil erosion tends to reduce plant cover and species diversity and hence leads to a deterioration of plant communities (Guerrero-Campo \& Montserrat-Martí 2000; Lázaro Suau 1995; Thornes 1990; Tsuyuzaki \& Titus 1996). Although some colonization by specialized species may occur in the earlier stages of erosive processes, plant colonization and species substitution are arrested when degradation is severe (Guardia 1995; Guardia \& Ninot 1992). In Mediterranean and semi-arid regions, many of the species that make part of plant communities in the stages of the erosion process previous to desertification are remains of the former well-developed vegetation. The analysis of the adaptive traits that enable the 
persistence of plants in eroded lands is, therefore, crucial to understand vegetation dynamics associated to erosive processes.

Soil erosion is a geomorphologic process that increases both the stress and frequency of disturbances affecting plants. Main stresses are related to a reduction in water and nutrient availability due to the loss of organic soil horizons; while disturbances comprise plant uprooting, dragging and breaking (Grime 2001). Many studies have assessed the relationship between certain morphological traits of plants and water and nutrient deficit (Danin \& Orshan 1990; Fernández Alés et al. 1993). Similarly, it is well known the effect of edaphic disturbances on the efficiency of some plant traits such as clonal reproduction or seeding strategy (Biondini et al. 1985; Tsuyuzaki \& Del Moral 1995;). However, only a few studies have assessed the response of plant species to processes causing a simultaneous increase in stress and disturbance, such as soil erosion. For example, a previous study on 29 attributes of plants from badlands, showed (without statistical testing) a greater frequency of perennial vs. annual plants and tap-rooted vs. fasciculate-root plants in eroded areas, while plants forming stolons or bulbs where completely absent (Guardia 1995). Navarro et al. found that most species growing in badlands showed a great plasticity in their vegetative growth (Navarro et al. 1993). Finally, Hodgson and collaborators concluded that soil erosion favoured stresstolerant species in the gypsum outcrops of NE Spain (Hodgson et al. 1994).

Certain attributes may favour plant survival in areas subjected to stress and frequent disturbances, such as highly eroded lands. For example, clonal reproduction favours plant colonization and persistence in resource-poor (Jónsdóttir \& Watson 1997; Shumway 1995) and disturbed areas (Bond \& Midgley 2001; Fahrig et al. 1994; Prach \& Pysek 1994). Clonal reproduction is related to the ability of plants to form shoots from the roots and/or to rootsprout (Del Tredici 2001; Groff \& Kaplan 1988; Klimesová \& Martínková 2004). These abilities seem to favour plant survival in areas where erosive and/or sedimentary processes prevail (Danin 1996; Dech \& Maun 2006; Del Tredici 1992; Sakai et al. 1995; Yu et al. 2004).

Groff \& Kaplan (1988) revised the different root:shoot relationships of rooted plants and differentiated four "structural classes": class 1: bipolar plant; plants lacking shoot-borne roots and root-borne shoots; class 2: plants with only shoot-borne roots, i.e. plants able to root from layered branches, stems, or stem-derived structures: rhizomes, stolons, lignotubers, etc.; class 3: plants with only root-borne shoots, i.e. plants with root systems able to produce shoots, know usually as root suckers; and class 4: plants with the ability to produce both shoot-borne roots and root-borne shoots. In a recent study, we have shown that the different shoot-rooting and root sprouting abilities of plant species described by Groff \& Kaplan are related to certain root system morphologies and ecological strategies (Guerrero-Campo et al. 2006). In particular, root-sprouters (classes 3 and 4) tended to have coarse and deep roots, whereas shoot-rooting species (mainly class 2 species) displayed fine, fasciculate, long and laterally spreading roots.

The application of these classes to describe the vegetation of eroded landscapes remains unexplored. Severely eroded areas comprise mosaics of sites with different soil depth, where contrasting erosive and sedimentary processes proceed at small scale, in different points of the slope. Plants growing in sites where soil erosion prevails tend to be uprooted, while the shoots of plants growing in sedimentary sites tend to be buried by sediments. Bipolar species (class 1) are unable to respond to such changes in soil depth, and hence a decrease in the abundance of these plants might be expected as the severity of the erosion process increases. On the other hand, root-sprouters (class 3 species) might be favoured in those sites where the loss of soil is 
more intense, whereas shoot-rooting species might dominate in areas where sedimentation prevails. Finally, class 4 species, i.e. those species able both to root-sprout and to form roots from the roots, might be the most plastic species in relation to erosive and sedimentary processes and hence highly resistant to both processes.

Several previous studies have demonstrated that adventitious root formation is an adaptive trait of plants growing in areas such as sand dunes or sedimentary sites where plants are frequently buried (Danin 1996; Dech \& Maun 2006; Franks \& Peterson 2003; Yu et al. 2004). For species growing in sand dunes, shoot-rooting ability increases in plants showing burial tolerance or specialization (Dech \& Maun 2006), and has been interpreted as a mechanism to increase plant access to oxygen, water and nutrients, and to improve mycorrhizal activity, once the soil conditions have been modified by burial (Dech \& Maun 2006; Yoshikawa \& Hukusima 1997). This study focuses on highly eroded badlands, where erosive processes are far more frequent than sedimentary processes and plant burial is rare. In such badlands sedimentation is restricted to the reduced retention of soil material due to plants or stones. Therefore, we will focus our analysis on the traits that enable the persistence of plants when erosive rather than sedimentary processes prevail.

The objective of this study was to explore the relationship between soil erosion and the frequency of root-sprouting, clonality and different growth forms in three eroded areas of NE Spain. Our expectation is that the frequency of root-sprouters will increase with soil erosion. We also expect the frequency of bipolar species to decrease as the erosive process proceeds.

\section{MATERIAL AND METHODS}

\section{Study area}

The area surveyed was located between the middle Ebro Valley and the Pre-Pyrenees (north-east Spain), and comprised the following substrates: almost pure gypsum outcrops, Miocene clays from the Somontanos and Eocene Pre-Pyrenean marls. Study sites were pastures on areas with medium to high levels of soil erosion, mostly intermingled mosaics of small patches with different grades of soil erosion and vegetation cover.

Gypsum outcrops were located in the Middle Ebro Basin, under a semi-arid climate (Table 1). Soils have a high infiltration capacity which leads to reduced runoff of rainwater and, consequently, moderate soil erosion (Desir 2002; Gutiérrez Elorza et al. 1995). Miocene clays were located between gypsum and marls, and hence present intermediate climatic features (Table 1). Soil infiltration rates are very low and soil erosion rates are intense (Gutiérrez Elorza et al. 1995). Eocene marls have sub-Mediterranean climate (Table 1). Bare soils on marls are very impermeable, with high water retention capacity and slow permeability, so runoff and soil erosion rates are intense, and formation of extensive gullies is frequent (Cervera et al. 1991). For more details about the study area and field survey see Guerrero-Campo \& Montserrat-Martí (2000; 2004).

\section{Data collection}

We obtained 260 vegetation relevés: 124 in almost pure gypsum hills near Zaragoza, 61 in Miocene clays around Huesca and 75 in Eocene marls around Jaca. To reduce climatic and edaphic variations within relevés from each substratum, we analyzed small close areas (less than $10 \mathrm{~km}$ away) with very similar soil and climate. Each relevé covered an area of a $3 \mathrm{~m}^{2}$ square. Different eroded sites were surveyed by taking relevés at varying levels of vegetation degradation and at different locations (with varying slope, position in the slope and aspect). .A high negative correlation between the degree of erosion and phanerogam cover 
was found in previous studies conducted in the same area (Guerrero-Campo \& MontserratMartí 2000; 2004). For this reason and to facilitate the comparison with other studies, 1phanerogam cover was used as an indicator of the degree of vegetation degradation caused by soil erosion. At each study site we selected close patches of degradation levels, generally ranging from moderately degraded patches (phanerogam cover usually $>75 \%$ ) to severely degraded ones (phanerogam cover usually $<10 \%$ ). A complete list of species present in every relevé was recorded.

Table 1. Location, climate and soil characteristics of the study area.

\begin{tabular}{|c|c|c|c|}
\hline & $\begin{array}{l}\text { Almost pure } \\
\text { gypsum }\end{array}$ & Miocene clays & Eocene marls \\
\hline $\begin{array}{l}\text { UTM (Universal Transverse Mercator) } \\
\text { coordinate }\end{array}$ & 30T6874613 & $30 \mathrm{~T} 7034668$ & 30T7274663 \\
\hline Mean altitude (m a.s.l.) & 290 & 560 & 830 \\
\hline Mean annual rainfall $(\mathrm{mm}$ year-1) & 320 & 570 & 820 \\
\hline Mean annual temperature $\left({ }^{\circ} \mathrm{C}\right)$ & 14.5 & 13.3 & 10.6 \\
\hline $\begin{array}{l}\text { Mean minimal temperature of the } \\
\text { coolest month }\left({ }^{\circ} \mathrm{C}\right)\end{array}$ & 1.5 & 0.5 & -0.2 \\
\hline $\mathrm{pH}$ & $7.3-8.36$ & $7.85-9.15$ & $7.96-8.99$ \\
\hline Conductivity $\left(\mathrm{mS} \mathrm{cm}^{-1}\right)$ & $0.18-2.42$ & $0.08-2.28$ & $0.08-0.21$ \\
\hline $\mathrm{CaCO}_{3}(\%)$ & $9.5-15.6$ & $31.1-37.8$ & $28.8-29.3$ \\
\hline Soil texture & Silty sand & $\begin{array}{l}\text { Clay or silty } \\
\text { clay }\end{array}$ & Silty loam \\
\hline Runoff coefficient (\%) & 32 & 75 & 50 \\
\hline
\end{tabular}

Root-sprouting and shoot-rooting ability, clonal reproduction and grow form were assessed for the 123 most frequent phanerogams found on scrub pastures and badlands in the study area. The selection of species followed a previous study on eroded areas on the same area where the most frequent species (those appearing in at least $5 \%$ of a total of 734 vegetation relevés) were identified (Guerrero-Campo et al., 2006). This large species set included most of the growth forms found in the study area, from shrubs to annual plants.

To estimate the different types of rooting or sprouting characteristics and the ability to perform clonal reproduction of each species, several eroded sites were surveyed in detail, particularly highly eroded surfaces, slopes on road cuts and sedimentary sites. Data were pooled with previous observations to build a large data base (see Supplementary Material in Guerrero-Campo et al., 2006). For each species the cases of observed root-borne shoots, shoot-borne roots and the distance of clones to the mother plant were recorded. There was continuous variation between the species that produced large amounts of shoot-borne roots and those that produced no shoot-borne roots. A similar variation pattern was observed with regard to root-borne shoots. However, in order to simplify the interpretation of results, and due to the great number of species analyzed, only the presence/absence of each trait was recorded. The distance between parent and offspring ramets was categorized in four classes: no clonality; short distance (when offspring ramets were attached to parent ramets); intermediate distance (when offspring ramets were closer than twice the parent ramets height); long distance (when offspring ramets were separated more than twice the parent ramets height). Finally, each species was ascribed to one of four different growth forms based on the degree of lignification: woody, woody stock, herbaceous perennial and herbaceous 
annual. Herbaceous species with woody stock are quite frequent in the communities analyzed $(8.2 \%)$. For this reason, we decided to consider them as a different category from other completely herbaceous species.

Table 2. Spearman coefficients for the correlation between soil erosion (1-phanerogam cover) and frequency of species with different classes of root:shoot relationships. Class 1: bipolar species; class 2: shoot-rooting species; class 3: root-sprouters and class 4: species with both the ability to rootsprout and to form roots from the shoots.

\begin{tabular}{lcccc}
\hline & Class 1 & Class 2 & Class 3 & Class 4 \\
\hline $\begin{array}{l}\text { Almost pure gypsum (n } \\
=124)\end{array}$ & $-0.564 * * *$ & $0.126 \mathrm{n.s}$ & $0.317 * * *$ & $0.520 * * *$ \\
$\begin{array}{l}\text { Miocene clays } \\
(\mathrm{n}=61)\end{array}$ & $-0.505 * * *$ & $0.379 * *$ & $-0.162 \mathrm{n} . \mathrm{s}$ & -0.179 n.s \\
$\begin{array}{l}\text { Eocene marls } \\
(\mathrm{n}=75)\end{array}$ & $-0.293 *$ & $-0.222 \mathrm{n} . \mathrm{s}$ & $0.235 *$ & -0.013 n.s \\
\hline
\end{tabular}

$* 0.05 \geq P>0.01 ; * * 0.01 \geq P>0.001, * * * P \leq 0.001$; n.s. not significant: $P>0.05$.

\section{Statistical analyses}

To estimate the frequency of each studied feature (i.e. growth form, clonality and type of root-shoot relationship), we calculated the frequencies in the relevés of species that shared the analysed attributes. These data were used for the analysis of the differences in the frequency of each feature among different soil erosion levels. Data were not normally distributed, and hence the relationship between soil erosion $(1-$ phanerogam cover $)$ and the frequency of the different traits was assessed by the non-parametric Spearman correlation coefficient (Zar 1984).To detect possible interactions between growth forms and root-shooting and root-sprouting abilities, we analyzed the distribution of growth forms among the four structural classes of Groff and Kaplan (1988). Differences between structural classes were assessed by the Log-likelihood ratio analyses $(G)$. All statistical analyses were conducted with SPSS 13.0 for Windows.

\section{RESULTS}

The following results show the variation in the frequency of characters due to the presence or absence of species in relevés from areas with different degree of soil erosion. Data calculated on a plant cover basis were strongly influenced by sudden changes in the occurrence of one or few dominant species. For this reason we decided to present data as a function of species frequency in relevés. Nevertheless results were quite similar in both cases (data not shown).

\section{Root-shoot relationship}

The frequency of bipolar species decreased with soil erosion in the three substrata analysed (Table 2). The frequency of shoot-rooting species (class 2) did not show significant correlation with erosion of marls and gypsum soils, but increased significantly with soil erosion in Miocene clays (Table 2). The frequency of root-sprouters (class 3) showed no significant correlation with the erosion of clays, but their frequency increased remarkably with erosion in gypsum and marls (Table 2). Finally, species with both the ability to rootsprout and to form shoots from their roots (class 4) increased their frequency significantly 
with soil erosion only in gypsum soils (Table 2).

The interaction between growth forms and the four root:shoot classes was significant after a $\mathrm{X}^{2}$ test: Likelihood test value $=13.58, \mathrm{P}=0.003$. Provided that many woody species are root-sprouters and most annuals are bipolar species (except for annual grasses which belong to class 2), we repeated the correlation analyses excluding woody species and annual species. When excluding annual species, significant correlations between the inverse of phanerogam cover (i.e. erosion degree) and frequency of bipolar species remained so in marls $(\mathrm{R}=-0.250, \mathrm{P}=0.030)$ and clays $(\mathrm{R}=-0.269, \mathrm{P}=0.036)$, but not in gypsum outcrops $(\mathrm{R}=-$ $0.022, \mathrm{P}=0.805)$. When woody species were excluded from the analysis, the increase of rootsprouters with soil erosion rendered significant in gypsum outcrops $(\mathrm{R}=0.258, \mathrm{P}=0.004)$ but not in marls $(\mathrm{R}=0.144, \mathrm{P}=0.216)$, while in clays there was no relationship in any case.

Table 3. Spearman coefficients for the correlation between vegetation degradation by soil erosion (1phanerogam cover) and frequency of species with different types of clonal reproduction.

\begin{tabular}{lcccc}
\hline & No clonality & Short distance & Intermediate distance & Long distance \\
\hline Almost pure gypsum (n & $-0.392 * * *$ & $0.446 * * *$ & $-0.415 * * *$ & $0.300 * * *$ \\
$=124)$ & & & \\
Miocene clays & $-0.145 \mathrm{n} . \mathrm{s}$ & $0.042 \mathrm{n} . \mathrm{s}$ & $-0.143 \mathrm{n} . \mathrm{s}$ & $0.124 \mathrm{n} . \mathrm{s}$ \\
$(\mathrm{n}=61)$ & & $-0.273 *$ & $0.113 \mathrm{n} . \mathrm{s}$ \\
$\begin{array}{l}\text { Eocene marls } \\
(\mathrm{n}=75)\end{array}$ & $-0.245 *$ & $0.084 \mathrm{n} . \mathrm{s}$ & \\
\hline $0.05 \geq P>0.01 ; * * 0.01 \geq P>0.001 ; * * * P \leq 0.001 ;$ n.s. not significant: $P>0.05$.
\end{tabular}

\section{Clonality}

Non-clonal species decreased their frequency as erosion increased in gypsum and marls, while no significant correlation was observed in clays (Table 3). Among clonal species, those species forming offspring ramets at a short distance from parent ramets were significantly more frequent in eroded areas of gypsum outcrops, but they showed no significant correlation with soil erosion in clays and marls (Table 3). Species with an intermediate distance of clone dispersion decreased their frequency with soil erosion in gypsum outcrops and marls, whereas species with a long distance of clone dispersion increased their frequency with soil erosion only in gypsum outcrops (Table 3).

Table 4. Spearman coefficients for the correlation between vegetation degradation by soil erosion (1phanerogam cover) and frequency of species with different growth forms.

\begin{tabular}{|c|c|c|c|c|}
\hline & Woody plants & Woody stock & $\begin{array}{l}\text { Herbaceous } \\
\text { perennials }\end{array}$ & Annuals \\
\hline $\begin{array}{l}\text { Almost pure gypsum (n } \\
=124)\end{array}$ & $0.646 * * *$ & -0.069 n.s & $-0.133 n . s$ & $-0.686 * * *$ \\
\hline $\begin{array}{l}\text { Miocene clays } \\
(\mathrm{n}=61)\end{array}$ & $0.445 * * *$ & -0.143 n.s & $-0.450 * * *$ & $-0.423 * * *$ \\
\hline $\begin{array}{l}\text { Eocene marls } \\
(\mathrm{n}=75)\end{array}$ & -0.030 n.s & $-0.295 * *$ & 0.169 n.s & $-0.300 * *$ \\
\hline
\end{tabular}

\section{Growth forms based in the degree of lignification}

The frequency of woody species increased significantly in the most degraded areas of 
gypsum outcrops and Miocene clays, while correlation was no significant in Eocene marls (Table 4). The majority of woody species that grew in the most eroded areas were sub-shrubs and, less frequently, shrubs (data not shown). Indeed, no trees were found at the most eroded sites in any of the studied substrata. Despite the different environmental conditions prevailing in the three substrata analyzed, annual species decreased their frequency with soil erosion in all of them (Table 4). The frequency of herbaceous perennials decreased significantly with soil erosion in Miocene clays, whereas that of species with woody stock showed negative correlation with soil erosion only in Eocene marls (Table 4).

\section{DISCUSSION}

Our results show that soil erosion increases the frequency of root-sprouters, clonal species and small woody plants but reduces the frequency of bipolar species and annual plants. These results indicate the adaptive significance of some traits of plants growing in eroded lands such as the ability to root-sprout or to perform clonal dispersion together with the advantage of certain growth forms such as woody sub-shrubs.

One of the main disturbances caused by soil erosion is plant uprooting (GuerreroCampo 1998). According to our observations, most species can survive a certain degree of uprooting, however, once a certain threshold is surpassed, plant canopy dries out and only root-sprouters survive. At a community level, where the intensity of soil erosion is not homogeneous, this leads to an increase in the frequency of root-sprouters. In this study, such relationship between root-sprouting and plant tolerance to soil erosion was significant in gypsum outcrops and Eocene marls, but it was not significant in Miocene clays. When woody species were excluded from the analysis, the positive relationship between soil erosion and the frequency of root-sprouters rendered significant only for gypsum outcrops, though statistical power was low. This indicates that there is an interaction between root-sprouting and woody growth form, so that many root-sprouters are sub-shrubs.

The lack of a significant relationship between root-sprouting and soil erosion in Miocene clays is surprising. One possible explanation might be that, as observed in previous studies (Guerrero-Campo \& Montserrat-Martí 2004), some dominant species of sedimentary areas of gypsum outcrops tend to colonize highly eroded sites in the more humid Miocene clays. Most of such colonizing plants are shoot-rooting species (class 2), which may obscure the relationship between root-sprouting and soil erosion tolerance in this substratum. This unexpected pattern of colonization of eroded lands by species from sedimentary sites of drier areas has also been observed in Eocene marls, though in this substratum it is much less frequent and conspicuous (Guerrero-Campo \& Montserrat-Martí 2004). The relationship between root-sprouting and the tolerance of plants to partial uprooting has been reported in a wide variety of species from different environments, such as perennial weeds (McIntyre 1979; Raju et al. 1966), riverine species subjected to recurrent floods (White 1979), or species from sand dunes in arid and semiarid areas (Danin 1996). Together with our results, these studies indicate that root sprouting is an adaptive trait common to different taxa from different environments where partial uprooting prevails.

According to our results, soil erosion favours the frequency of species with the ability to reproduce vegetatively against those that can just reproduce by seeding, such as annuals or most bipolar plants. Previous studies on seed germination have demonstrated that seed banks from badlands are diverse and abundant enough to enable the reconstruction of former plant communities (García-Fayos et al. 1995; Guàrdia et al. 2000a). Indeed, sexual reproduction is 
more relevant than vegetative reproduction to the spatial spread of some key species from badlands (Guàrdia et al. 2000b). However, in most eroded sites colonization from seed banks is hampered by the presence of highly compacted bare soils and intense water and nutritional deficits, which limit seed germination and seedling growth (Guardia 1995). Vegetative reproduction is, thus, the unique effective mechanism for most species to colonize and persist in highly eroded areas (Guerrero-Campo 1998). Clonal reproduction has been shown to enable plant survival in frequently disturbed sites (Fahrig et al. 1994; Prach \& Pysek 1994), especially when resources are scarce (Grubb 1985; Shumway 1995), but see Klimesová \& Martínková (2004). Similarly, previous studies indicate that species following a persistence strategy against disturbances, such as sprouters, tend to increase with increasing frequency of disturbances and are likely to be more frequent in unproductive than productive sites (Bellingham \& Sparrow 2000; Bond \& Midgley 2001).

This study indicates that the species with a long distance of clonal dispersion tend to resist soil erosion better than those species forming offspring ramets at medium distance to the parent ramet. An extensive clonal integration is advantageous in resource-poor environments where resources are patchily distributed, as clonality enables plants to sample the environment at multiple sites (Jónsdóttir \& Watson 1997). Accordingly, plants with a long distance of clonal dispersion can colonize areas where resources are scarce thanks to their ability to translocate resources from other ramets growing in favourable microsites (Shumway 1995; Yu et al. 2004). Long-distance clonal growth is also relevant for the colonization and persistence of plants in disturbed areas (Belsky 1986; Prach \& Pysek 1994). For example, an extensive clonal integration entails a greater ability to survive deep sand burial in dunes (Yu et al. 2004).

The great difficulties associated with badlands colonization by seeding explain the significant reduction of annual plants in the most eroded areas of the three substrata analysed. Annual plants are known to be well-adapted to colonize disturbed environments. Accordingly, they display high relative growth rates (RGR), need moderate or high soil fertility and produce numerous seeds (Grime 2001). However, when disturbed areas are subjected to a certain degree of stress, pioneer species are no longer annuals, but longer-lived species with lower RGR (Borgegard 1990; Grubb 1985). A scarcity in annual species has repeatedly been reported in highly eroded lands and gullies (Biondi et al. 1988; Guardia 1995; Korzgebevskii \& Klyukin 1990; Tsuyuzaki \& Titus 1996), though certain studies in arid eroded sites have shown that annuals can also be important in some of these areas (Ferrari \& Gerdol 1987; Gurrea Guerrero et al. 1995; Lázaro Suau 1995).

Our results show that woody species (in this study represented mainly by study subshrubs) have a greater ability to persist in highly eroded areas than other growth forms, particularly in the most arid substrate (gypsum outcrops). Most Mediterranean sub-shrubs are typically considered stress-tolerant, but show also a certain ability to survive disturbances (Margaris, 1981; Palacio et al. 2006). Their predominance in the most eroded sites of gypsum outcrops may be explained because the abiotic stresses generated by soil erosion in these semiarid areas are greater than in more humid substrates, where they are excluded from competition (García-Fayos et al. 2000). At the same time, disturbances may be less intense, as the rate of soil erosion is lower than in more dynamic areas, such as the clays and marls studied. Contrastingly, in the most humid substrate analysed (Eocene marls), disturbances by dragging and breaking could be more limiting for plant growth than the abiotic stresses generated by soil erosion (Guerrero-Campo 1998; Guerrero-Campo \& Montserrat-Martí 
2000). This might explain the high frequency of herbaceous perennials and the reduced frequency of woody species (sub-shrubs) observed in this substrate (Guerrero-Campo 1998). It is remarkable that tall shrubs and trees were generally absent from the severely eroded areas considered in this study.

In conclusion, our results indicate that bipolar species tend to decrease their frequency with soil erosion while root-sprouters tend to increase, although this relationship was not apparent in Miocene clays. Root-sprouting favours plant persistence with soil erosion, while shoot-rooting could be adequate to survive burial. Therefore, those species unable to either root-sprout or shoot-root, i.e bipolar species, tend to decrease when erosive-sedimentary processes are intense. These trends may be somehow affected by an interaction with growth form, as most annuals are bipolar species and many root-sprouters are sub-shrubs. Due to the combined conditions of high stress and frequent disturbances prevailing in eroded areas, species with clonal reproduction, especially at long distances, and perennial species like small woody or herbaceous plants, tend to resist the strong soil erosion processes better than other plant types, such as annual plants.

\section{ACKNOWLEDGEMENTS}

This study was supported by the research projects RTA 2005-00100 from the MEC (INIA) and CGL2006-11619/HID, CGL2004-04919-C02-01/HID, REN2003-08678/HID from the MCT, Spanish Government. J. G. C. was supported by a grant from the Government of Aragon (BMA 15/93). Prof. Begoña Peco, Miguel Verdú and four anonymous referees provided helpful comments to former versions of the manuscript.

\section{REFERENCES}

Bellingham, P.J., \& Sparrow A.D. 2000. Resprouting as a life history strategy in woody plant communities. Oikos 89: 409-416.

Belsky, A.J. 1986. Revegetation of artificial disturbances in grasslands of the Serengeti National Park, Tanzania. I. Colonization of grazed and ungrazed plots. J. Ecol. 74: 419-437.

Biondi, E., Allegrezza, M., Guitian, J., \& Taffetani, F. 1988. La vegetazione dei calanchi di Sasso Simone e Simoncello (Appennino tosco-marchigiano). Braun-Blanquetia 2: 105-115.

Biondini, M.E., Bonham, C.D., \& Redente, E.F. 1985. Secondary successional patterns in a sagebrush (Artemisia tridentata) community as they relate to soil disturbance and soil biological activity. Vegetatio 60: 25-36.

Bond, W.J., \& Midgley, J.J. 2001. Ecology of sprouting in woody plants: the persistence niche. Trends Ecol. Evol. 16: 45-51.

Borgegard, S.O. 1990. Vegetation development in abandoned gravel pits: effects of surrounding vegetation, substrate and regionality. J. Veg. Sci. 1: 675-682.

Cervera, M., Clotet, N., Guardia, R., \& Sole-Sugrañes, L. 1991. Response to rainfall simulation from scarcely vegetated and non-vegetated badlands. Catena suppl. 19: 39-56.

Danin, A. 1996. Plants of desert dunes. Springer, Berlin.

Danin, A., \& Orshan, G. 1990. The distribution of Raunkiaer forms in Israel in relation to the environment. J. Veg. Sci. 1: 41-48. 
Dech, J.P., \& Maun, M.A. 2006. Adventitious root production and plastic resource allocation to biomass determine burial tolerance in woody plants from Central Canadian coastal dunes. Ann. Bot. 98: 1095-1105.

Del Tredici, P. 1992. Natural regeneration of Ginkgo biloba from downward growing cotyledonary buds (basal chichi). Am. J. Bot. 79: 522-530.

Del Tredici, P. 2001. Sprouting in temperate trees: a morphological and ecological review. Bot. Rev. 67: 121-140.

Desir, G. 2002. Hydrological response types for gypsiferous soils in a semi-arid region during nine years of continuous record. Hydrol. Process. 16: 2685-2700.

Fahrig, L., Coffin, D.P., Lauenroth, W.K., \& Shugart, H.H. 1994. The advantage of longdistance spreading in highly disturbed habitats. Evol. Ecol. 8: 172-187.

Fernández Alés, R., Laffarga, J.M., \& Ortega, F. 1993. Strategies in Mediterranean grassland annuals in relation to stress and disturbance. J. Veg. Sci. 4: 313-322.

Ferrari, C., \& Gerdol, R. 1987. Numerical syntaxonomy of badland vegetation in the Apennines (Italy). Phytocoenologia 15: 21-37.

Franks, S.J., \& Peterson, C.J. 2003. Burial disturbance leads to facilitation among coastal dune plants. Plant Ecol. 168: 13-21.

García-Fayos, P., García-Ventoso, B., \& Cerdà, A. 2000. Limitations to plant establishment on eroded slopes in southeastern Spain. J. Veg. Sci. 11: 77-86.

García-Fayos, P., Recatalá, T.M., Cerdá, A., \& Calvo, A. 1995. Seed population dynamics on badland slopes in southeastern Spain. J. Veg. Sci. 6: 691-696.

Grime, J.P. 2001. Plant strategies, vegetation processes, and ecosystem properties. 2nd ed. John Wiley \& Sons, LTD, Chichester, U.K.

Groff, P.A., \& Kaplan, D.R. 1988. The relation of root systems to shoot systems in vascular plants. Bot. Rev. 54: 387-421.

Grubb, P.J. 1985. Plant populations and vegetation in relation to habitat, disturbance and competition: problems of generalization. In: White, J. (ed). The population structure of vegetation, pp 595-621. W. Junk Publishers, Dordrecht.

Guardia, R. 1995. La colonització vegetal de les áreas erosionades de la conca de la Baells (Alt Llobregat). PhD Thesis. Universitat de Barcelona, Spain.

Guàrdia, R., Gallart, F., \& Ninot, J.M. 2000a. Soil seed bank and seedling dynamics in badlands of the Upper Llobregat basin (Pyrenees). Catena 40: 189-202.

Guardia, R., \& Ninot, J.M. 1992. Distribution of plant communities in the badlands of the upper Llobregat basin (Southeastern Pyrenees). Studia Geobotanica 12: 83-103.

Guàrdia, R., Raventós, J., \& Caswell, H. 2000b. Spatial growth and population dynamics of a perennial tussock grass (Achnatherum calamagrostis) in a badland area. J. Ecol. 88: 950-963.

Guerrero-Campo, J. 1998. Respuestas de la vegetación y de la morfología de las plantas a la erosión del suelo. Valle del Ebro y Prepirineo Aragonés. Serie Investigación no12. Consejo de Protección de la Naturaleza de Aragón, Zaragoza, Spain.

Guerrero-Campo, J., \& Montserrat-Martí, G. 2000. Effects of soil erosion on the floristic composition of plant communities on marl in northeast Spain. J. Veg. Sci. 11: 329-336.

Guerrero-Campo, J., \& Montserrat-Martí, G. 2004. Comparison of floristic changes on vegetation affected by different levels of soil erosion in Miocene clays and Eocene marls from Northeast Spain. Plant Ecol. 173: 83-93.

Guerrero-Campo, J., Palacio, S., Pérez-Rontomé, C., \& Montserrat-Martí, G. 2006. Effect of 
root system morphology on root-sprouting and shoot-rooting abilities in 123 plant species from eroded lands in North-east Spain. Ann. Bot. 98: 439-447.

Gurrea Guerrero, M.M., Jiménez Martínez, M.A., Berrad, F., \& García-Rosell. 1995. La vegetación en una zona de badlands (Albox-Almería). Studia Oecologica 12: 173-182.

Gutiérrez Elorza, M., Sancho Marcén, C., Desir Valen, G., Sirvent Mira, J., Benito Ferrández, G., \& Calvo Cases, A. 1995. Erosión hídrica en terrenos arcillosos y yesíferos de la Depresión del Ebro. Universidad de Zaragoza-ICONA, Zaragoza, Spain.

Hodgson, J., Montserrat, G., Alberto, F., García Ruiz, J.M., Guerrero, J., \& Colasanti, R. 1994. A comparison of the functional characteristics of plants from sedimenting and eroded areas with particular reference to the gypsum hills of the Ebro Depression. In: Arnáez, J., García Ruiz, J.M., \& Gómez Villar, A. (eds.) Geomorfología en España, pp 239-251. Sociedad Española de Geomorfología, Logroño, Spain.

Jónsdóttir, I.S., \& Watson, M.A. 1997. Extensive physiological integration: an adaptative trait in resource-poor environments. In: de Kroon, H., \& van Groenendael, J. (eds.) The ecology and evolution of clonal plants, pp 109-136. Backbuys Publishers, Leiden, The Netherlands.

Klimesová, J., \& Martínková, J. 2004. Intermediate growth forms as a model for the study of plant clonality functioning: an example with root sprouters. Evol. Ecol. 18: 669-681.

Korzgebevskii, V.V. \& Klyukin, A.A. 1990. Vegetation of Crimean badlands. The Soviet Journal of Ecology 20: 338-344.

Lázaro Suau, R. 1995. Relaciones entre vegetación y geomorfología en el área acarcavada del Desierto de Tabernas. Ph D. Thesis. Estación Experimental de Zonas Aridas, Almería, Spain.

Margaris, N.S. 1981. Adaptive strategies in plants dominating Mediterranean-type ecosystems. In: F. Di Castri, D. W. Goodall \& R. L. Specht (eds.) Mediterranean-Type Shrublands, pp. 309-315. Elsevier, Amsterdam, The Netherlands.

McIntyre, G.I. 1979. Developmental studies on Euphorbia esula. Evidence for water as a factor in the mechanism of root bud inhibition. Can. J. Bot. 57: 2572-2581.

Navarro, T., Nieto Caldera, J.M., Pérez Latorre, A.V. \& Cabezudo, B. 1993. Estudios fenomorfológicos en la vegetación del sur de España. III. Comportamiento estacional de una comunidad de badlands (Tabernas, Almería. España). Acta Botanica Malacitana 18: 189-198.

Palacio, S., Millard, P., \& Montserrat-Martí, G. 2006. Aboveground biomass allocation patterns within Mediterranean sub-shrubs: a quantitative analysis of seasonal dimorphism. Flora 201: 612-622.

Prach, K. \& Pysek, P. 1994. Clonal plants - what is their role in succession? Folia Geobot. Phytotax. (Praha) 29: 307-320.

Raju, M.V.S., Coupland, R.T. \& Steeves, T.A. 1966. On the occurrence of root buds on perennial plants in Saskatchewan. Can. J. Bot. 44: 33-37.

Sakai, A., Ohsawa, T., \& Ohsawa, M. 1995. Adaptive significance of sprouting of Euptelea polyandra, a deciduous tree growing on steep slopes with shallow soil. J. Plant Res. 108: 377-386.

Shumway, S.W. 1995. Physiological integration among clonal ramets during invasion of disturbance patches in a New England salt marsh. Ann. Bot. 76: 225-233.

Thornes, J.B. 1990 (ed.). Vegetation and erosion. British Geomorphological Research Group. Symposia Series. John Wiley \& Sons, Chichester, U.K. 
Tsuyuzaki, S. \& Del Moral, R. 1995. Species attributes in early primary succession on volcanoes. J. Veg. Sci. 6: 517-522.

Tsuyuzaki, S. \& Titus, J. 1996. Vegetation development patterns in erosive areas on the Pumice Plains of Mount St. Helens. Am. Midl. Nat. 135: 172-177.

White, P.S. 1979. Pattern, process and natural disturbance in vegetation. Bot. Rev. 45: 229-299.

Yoshikawa, M., \& Hukusima, T. 1997. The impact of extreme runoff events from the Sakasagawa river on the Senjogahara ecosystem, Nikko National Park. V. The importance of adventitious root systems for the burial tolerance of different tree species. Ecol. Res. 12: 39-46.

Yu, F., Dong, M. \& Krüsi, B. 2004. Clonal integration helps Psammochloa villosa survive sand burial in an inland dune. New Phytol. 162: 697-.

Zar, J.H. 1984. Biostatistical Analysis. Prentice-Hall, London. 